\title{
Enhance of Impermeability of the Soil using Fines from Recycled Construction and Demolition Waste
}

\author{
Tkiouat Chafiq and Cherradi Toufik \\ Mohammadia School of Engineers, University Mohammed V Agdal, \\ Rabat, Morocco
}

\begin{abstract}
Now a days, it is accepted that the reuse of recycled aggregates from construction and demolition waste in the production of concrete within an acceptable range of substitution of the natural aggregates comes with an economic and environmental benefit. The barrier design for solid waste confinement with a mixture of sand and sodium bentonite has already been studied and showed great results. But for clay to be extracted and transported to disposal sites, the transportation comes with a high price and especially, when it's not available nearby. This study comes to focus not only on the reuse of the construction and demolition waste but to reduce the cost of the extension of a landfill and the preservation of the soil and water environment. In this study we'll try to point another use of the recycled construction and demolition waste while extending the capacity of a landfill and construction of the cells. The fines from recycled construction and demolition waste should be used in a mixture with the local soil to enhance its impermeability, to prevent leakage from geomembrane puncturing.
\end{abstract}

Key words: Landfill, permeability, recycled fine aggregates, construction and demolition waste, sand and sodium, preservation

\section{INTRODUCTION}

The Waste from Demolition and Construction (CDW) is more and more available due to all rebuilding and rehabilitation of Moroccan cities such as the VSB program that allows all the cities in Morocco to restructure the shantytowns by demolishing and rebuilding new structured sites to absorb the population's need of housing in a more appropriate condition of living.

All the waste that comes as a result from the construction and demolition activities in Morocco ends up mixed with organic waste and then tossed in cells of landfills which is one of the principal causes of the differential settlement that loosen up the impermeability of the cover in closed landfills.

The modern landfill design should prevent the migration of fluids to the ground water using geomembranes from PEHD combined with clay liners to prevent leakage from geomembrane puncturing. The compacted clay liner also presents the risk of leakage from shrinkage that problem was treated in several studies and the treatment was a mixture liner of sand and clay but the nature of clay still depends on the type locally available.

Cementation of the fines from RAC that contain unhydrated cement should also be a factor in the enhancement of the hydraulic containment of the soil. In this study, we 'll present the possibility to improve of the impermeability of the soil in Larache Region in Morocco by mixing it with recycled fines from Construction and Demolition Waste (CDW).

\section{Literature review}

Previous studies: The requirements for an efficient barrier designed for solid waste confinement are:

- Adequate shear strength to maintain barrier stability

- A low hydraulic conductivity $\mathrm{k}$ bellow the value of 10 $\mathrm{cm} / \mathrm{sec}$

. A minimal shrinkage potential to minimize cracking with $<10 \%$ shrinkage

The matter of the impermeability of the sand-bentonite mixture has already been studied many

Corresponding Author: Tkiouat Chafiq, Mohammadia School of Engineers, University Mohammed V Agdal, Rabat, Morocco 
times in the past years and the results came satisfying for a mixture that has $10 \%$ of bentonite and has shown values of hydraulic conductivity ( $\mathrm{k}$ around 10 ) also based on the results of $\mathrm{k}$ tests Garlanger as. (1987) indicated that a minimum $\mathrm{BC}$ of $6 \%$ was required to achieve an adequate distribution of bentonite in the compacted SB mixture with a low $\mathrm{k}$ of $1 \times 10^{\circ} \mathrm{m} / \mathrm{sec}$. Cowland and Leung (1991) reported bentonite-soil mixtures with $5 \% \mathrm{BC}$ resulted in an uneven distribution of bentonite in the soil matrix and recommended a minimum $\mathrm{BC}$ of $7 \%$ for soil-bentonite liners to prevent preferential flow paths. Kenney eas. (1992) also found that the bentonite cannot be adequately distributed within compacted $\mathrm{SB}$ mixtures with $\mathrm{BC}$ values $<7 \%$.

Objective of the study: The main objective of the study is to find a possibility to substitute the bentonite in the sand-bentonite mixtures that has already shown great results as barriers for solid waste confinement in order to preserve ground water from lixiviate leakage. There are few studies focused on the recycled concrete particles smaller than $63 \mu \mathrm{m}$. Normally, recycled particles of this size are considered as the unusable fraction or of little use.

On this study, we discuss the possibility to reuse this last fraction (with a particle size under $63 \mu \mathrm{m}$ ) to enhance the impermeability of the soil based on the physical clogging of the fines in the soil (Fig. 1):

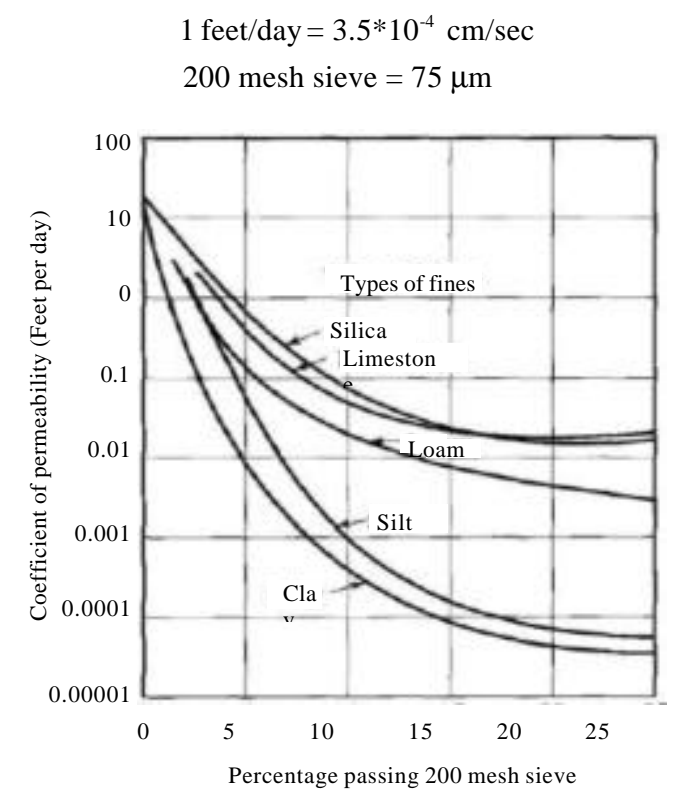

Fig. 1: Effect of different types of fines on permeability of coarse aggregate (Haung, 2003)

\section{CHARACTERIZATION OF FINES FROM RECYCLED CONSTRUCTION AND DEMOLITION WASTE}

The fines from recycled CDW The main objective is to lower the conductivity of the natural soil by filling the voids with the filler produced from the recycling process of the CDW. When wet, the clay fills the sand voids producing a very low hydraulic conductivity of the mixture.

There are few studies that focused on the recycled concrete particles smaller than $150 \mu \mathrm{m}$. Normally, recycled particles of this size are considered as the unusable fraction or of little use as filler. Particles smaller than $150 \mu \mathrm{m}$ are a similar size to cement particles, the main components are the cement hydration products, unhydrated cement, particles of original fine aggregates and crushed quartz particles from the original aggregates. Because the hydration of cement is not complete, particles of this size have a certain but not completed degree of hydration. There is a possibility to use recycled particles of this size as the replacement of cement in new concrete production. Shui a a. (2008) used a thermal treatment method to make dehydrated cement paste. The rehydration of the dehydrated cement paste can obtain a certain degree of strength, especially, when mixed together with fly ash (Shui as., 2008). It can be seen that recycled concrete particl es smaller than $63 \mu \mathrm{m}$ can be used as the binder material in new concrete but just some

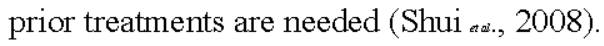

The fraction of fine recycled aggregates discussed in this study is the one with a particle size smaller than $63 \mu \mathrm{m}$. There is a high content of particles sized below 63 $\mu \mathrm{m}$, leading to an increased water demand during mixing and that property makes this particular fraction similar to clay. That when mixed with the local soil will cause a physical clogging.

\section{DENTIFICATION OF THE SOIL OF THE SPECIFIC CASE OF LARACHE CITY}

The identification of the soil presented in the Table 1 is based on three samples near the public landfill of Larache city.

The nature of the soil is a silty sand from the SM group according to ASTM D2487 as we can see from the grading size distribution on (Fig. 2). Using the empiric equation suggested by Hazen for filter sand:

$$
\mathrm{k}=\mathrm{C}_{\mathrm{k}} \mathrm{D}_{10}^{2}
$$


Res. J. Applied Sci., 14 (2): 54-56, 2019

Table 1: Identification of the soil from three different locations around the landfill of Larache city

\begin{tabular}{|c|c|c|c|c|c|c|}
\hline \multirow[b]{2}{*}{ Sample $N^{\circ} 17 / 283.3$} & \multirow[b]{2}{*}{ Depth (m) } & \multirow[b]{2}{*}{$\begin{array}{l}\text { Nature of the sample } \\
\text { color consistance structure }\end{array}$} & \multirow{2}{*}{$\begin{array}{l}\text { Methylene blue test } \\
\text { NF P 94-068 }\end{array}$} & \multicolumn{3}{|c|}{ Particle size ditribution } \\
\hline & & & & $\%<50(\mathrm{~mm})$ & $\%<2(\mathrm{~mm})$ & $\%<0.080(\mathrm{~mm})$ \\
\hline $2126 / 3$ & 0.65 & Red silty sand & 0.57 & 100 & 99 & 20.5 \\
\hline $2127 / 6$ & 0.70 & Red silty sand & 0.33 & 100 & 98 & 12.0 \\
\hline $2126 / 12$ & 0.70 & Red silty sand & 0.55 & 100 & 100 & 15.9 \\
\hline
\end{tabular}

Table 2: Values of Hazen's coefficient (Huang et al. 2003)

\begin{tabular}{lll}
\hline Soil type & $\mathrm{D}_{10}$ range $(\mathrm{mm})$ & $\mathrm{C}_{\mathrm{k}}(1 / \mathrm{mm}-\mathrm{sec})$ \\
\hline Uniform sand & $0.06-3.0$ & $8-12$ \\
Well-graded sands and silty sands & $0.003-0.6$ & $5-8$ \\
\hline
\end{tabular}

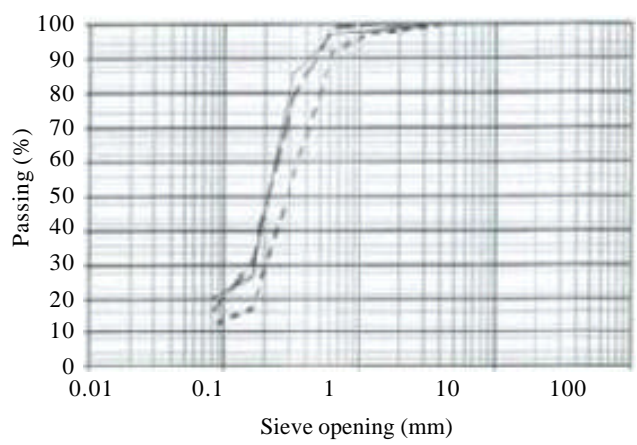

Fig. 2: Grading size distribution of the samples identified in Table 2

in which $\mathrm{k}$ is the permeability in $\mathrm{mm} / \mathrm{sec}, \mathrm{D}$. is the effective size or the grain size corresponding to $10 \%$ passing and C. is an experimental coefficient dependent on the nature of soil.

Based on Hazen formula and the values of $\mathrm{Ck}$ and D10 given in Table 2, the permeability of the soil in our case cannot go below $4.5^{*} 10-6 \mathrm{~cm} / \mathrm{sec}$.

\section{CONCLUSION}

This study came to analyze the possibility to reproduce the results obtained from the sand-bentonite mixture from a mixture of fines from recycled CDW with particle size bellow $63 \mu \mathrm{m}$ and the soil near any landfill to create an efficient barrier designed for solid waste confinement, based on the physical clogging of the fines in a granular drainage and filter material.
The fines from CDW can be assimilated to clay and can be used in a mixture with silty sand soil of Larache Region in a proportion close to proportions to achieve a low hydraulic conductivity $\mathrm{k}$ bellow the value of $10^{\circ} \mathrm{cm} / \mathrm{sec}$.

\section{RECOMMENDATIONS}

The future work will be consisting on the experimental process of the mixture, to find the adequate range of percentage of fines from CDW that should be added to the existing soil to cause an effective clogging in order to obtain the value of $\mathrm{k}$ bellow $10^{\circ} \mathrm{cm} / \mathrm{sec}$.

\section{REFERENCES}

Cowland, J.W. and B.N. Leung, 1991. A field trial of a bentonite landfill liner. Waste Manage. Res., 9: 277-291.

Garlanger, J.E., F.K. Cheung and S.T. Bishar, 1987. Quality Control Testing for a Sand-Bentonite Liner. In: Geotechnical Practice for Waste Disposal '87, Woods, R.D. (Ed.). American Society Of Civil Engineers, Reston, Virginia, USA., ISBN: 9780872626041, pp: 488-499.

Huang, Y.H., 2003. Pavement Analysis and Design. 2ndEdn., Prentice Hall, Prentice, SBN: 0-13-142473-4.

Kenney, T.C., W.V. Veen, M.A. Swallow and M.A. Sungaila, 1992. Hydraulic conductivity of compacted bentonite-sand mixtures. Canadian Geotech. J., 29: 364-374.

Shui, Z., D. Xuan, H. Wan and B. Cao, 2008. Rehydration reactivity of recycled mortar from concrete waste experienced to thermal treatment. Constr. Build. Mater., 22: 1723-1729. 